\title{
An Original Testing Apparatus for Rapid Pull-Out Test
}

\author{
Aprialdi, D. ${ }^{*}$, Lambert, S. ${ }^{2}$, Jenck, O. ${ }^{3}$, Erizal $^{4}$, and Widyarti, M. ${ }^{4}$
}

\begin{abstract}
Pull-out test is commonly used to investigate the pull-out behavior of geotextile reinforcement embedded in soil. It is also used by different authors to propose interface friction angles values. Unfortunately these works mainly deal with cyclic loadings with reference to seismic action, which are believed to be different to the load exposed to reinforced earthworks due to lateral impacts. Therefore an original rapid pull-out test apparatus is proposed in this study. This article assess the proposed test method in addressing the rapid pull-out response of a geotextile embedded in soil. The testing apparatus allows investigating shear velocities within the range of 0.1 to $1.2 \mathrm{~m} / \mathrm{s}$. This test method seems promising in addressing the response of soilgeotextile interfaces under dynamic loadings. Nevertheless, improvements concerning the testing apparatus are still required. The loading system could be modified to avoid oscillations and specific equipment should be added to increase the normal stress.
\end{abstract}

Keywords: Dynamic loading; pull-out test; soil-geotextile interface.

\section{Introduction}

The characteristics of the soil-geotextile interface have been addressed by many authors based on different test methods, in particular the direct shear test and the pull-out test [1-4]. Pull-out test is commonly used to investigate the pull-out behavior of reinforcement embedded in soil. It is also used by different authors to propose interface friction angles values (Tabel 1).

A pull-out device consists of a tank with rigid walls, frontal clamp and external (and sometimes internal) measurement devices (Figure 1). The pull-out resistance obtained from a pull-out test is not a function of the friction angle alone, but is a combination of the geotextile material behavior under tensile loading and the interface friction. Indeed, even if reinforcement geotextiles exhibit a high stiffness, their deformation has been shown to be of significant influence on the pull-out resistance $[4,5]$.

In terms of dynamic response of the interface with a geosynthetic, existing works mainly deal with cyclic loadings, with reference to seismic actions.

1,4 Civil and Environmental Engineering, Faculty of Agricultural Engineering and Technology, Bogor Agricultural University, Kampus IPB Darmaga, Bogor, West Java, INDONESIA, 16688.

${ }^{2}$ Irstea, UR ETGR, 2 rue de la papeterie, F-38402 St-Martin d'Hères, FRANCE.

${ }^{3}$ Laboratoire Sols, Solides, Structures et Risques (3SR), Joseph Fourier University, Grenoble INP, CNRS, Grenoble, FRANCE.

*Correspponding author, e-mail: dwinataaprialdi@gmail.com.

Note: Discussion is expected before November, $1^{\text {st }} 2014$, and will be published in the "Civil Engineering Dimension" volume 17, number 1, March 2015.

Received 08 November 2013; revised 12 March 2014; accepted 12 May 2014.
Table 1. Examples of Friction Angles derived from PullOut Tests on Geotextiles

\begin{tabular}{|c|c|c|c|c|}
\hline $\begin{array}{l}\text { Refe- } \\
\text { rence }\end{array}$ & Geotextile type & $\begin{array}{c}\text { Type of } \\
\text { Soil }\end{array}$ & $\begin{array}{l}\text { Tensile stress } \\
\text { response }\end{array}$ & $\begin{array}{c}\text { Interface } \\
\text { friction } \\
\text { angle }\end{array}$ \\
\hline [2] & $\begin{array}{l}\text { Needle-punched } \\
\text { nonwoven } \\
\text { polypropylene }\end{array}$ & $\begin{array}{l}\text { Sabkha } \\
\text { sand }\end{array}$ & $\begin{array}{l}20 \mathrm{kN} / \mathrm{m} \text { at } \\
70 \% \text { axial } \\
\text { deformation }\end{array}$ & $46^{\circ}-28^{\circ}$ \\
\hline [5] & $\begin{array}{l}\text { Woven } \\
\text { polypropylene } \\
\text { (extruded) }\end{array}$ & $\begin{array}{l}\text { Leighton } \\
\text { Buzzard } \\
\text { sand }\end{array}$ & $\begin{array}{l}17.3 \mathrm{kN} / \mathrm{m} \text { at } \\
28.5 \% \text { axial } \\
\text { deformation }\end{array}$ & $29^{\circ}-13^{\circ}$ \\
\hline [6] & $\begin{array}{l}\text { Woven polyester } \\
\text { (high strength) }\end{array}$ & $\begin{array}{l}\text { Compacted } \\
\text { clean river } \\
\text { sand }\end{array}$ & $508 \mathrm{kN} / \mathrm{m}$ & $28^{\circ}$ \\
\hline [7] & $\begin{array}{l}\text { HDPE geotextile } \\
\text { (rough surface) }\end{array}$ & $\begin{array}{l}\text { Rounded } \\
\text { silica sand }\end{array}$ & $\begin{array}{l}29 \mathrm{kN} / \mathrm{m} \text { at } \\
\text { yield, } \\
8 \mathrm{kN} / \mathrm{m} \text { at } \\
\text { rupture }\end{array}$ & $45^{\circ}$ \\
\hline
\end{tabular}

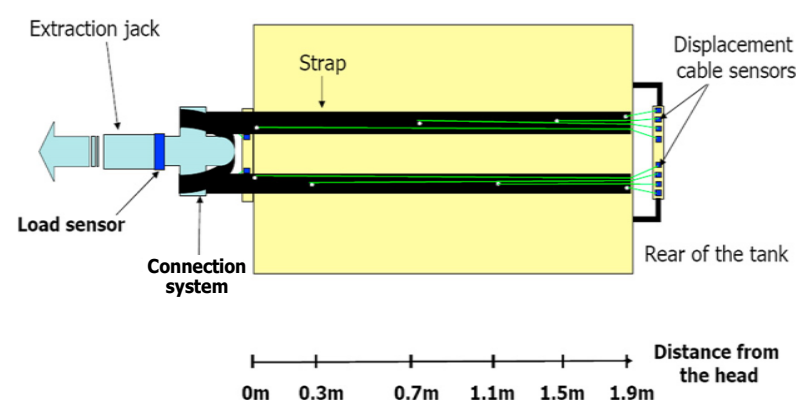

Figure 1. Example of a Pull-out Apparatus [1].

Some of these works deal with laboratory tests conducted on geosynthetic-geosynthetic interfaces [8], others deal with soil-geosynthetic interfaces based on small-scale structure experiments [9]. But the loading conditions are believed to be different to that prevailing in reinforced earthworks exposed to lateral impacts or dynamic loadings. 
In mountainous areas, embankments, dykes, levees or breaking mounds are often used as protection structures against natural hazards, for instance with the aim of slowing down, deviating or containing snow avalanches, rockfalls, and mudflows. The action of such natural events results in a dynamic loading oriented horizontally, perpendicular to the structure facing. This strongly contrasts with more classical geotechnical structures mainly exposed to static and vertically oriented loadings (e.g. gravity loadings).

For static stability reasons, these structures are most often reinforced with horizontal inclusions such as geotextile or geogrid layers. These horizontal planar reinforcement layers are parallel to the dynamic loading applied to the structure and thus potentially offer a preferential plane for shear rupture. This has been evidenced based on real-scale tests on rockfall protection embankments as well as on actual snow avalanche breaking mounds (Figure 2).

The soil-geotextile interaction is thus of paramount importance, especially the soil-geotextile friction. Designers most often model the geotextile-soil friction considering the Mohr-Coulomb failure criteria and using friction angles and cohesion values derived from static tests [10,11]. Besides, specific rockfall protection embankment design methods are based on the friction angle between the geotextile and the soil to compute the energy dissipated in the embankment [11].

This paper describes the development of a testing method specifically dedicated to the characterization of the soil-geotextile interface under conditions relevant to the geotechnique application. This testing apparatus is based on the rapid pull-out of a geotextile strip embedded in soil. This study provides the very first dynamic pull-out test results, varying the loading conditions.

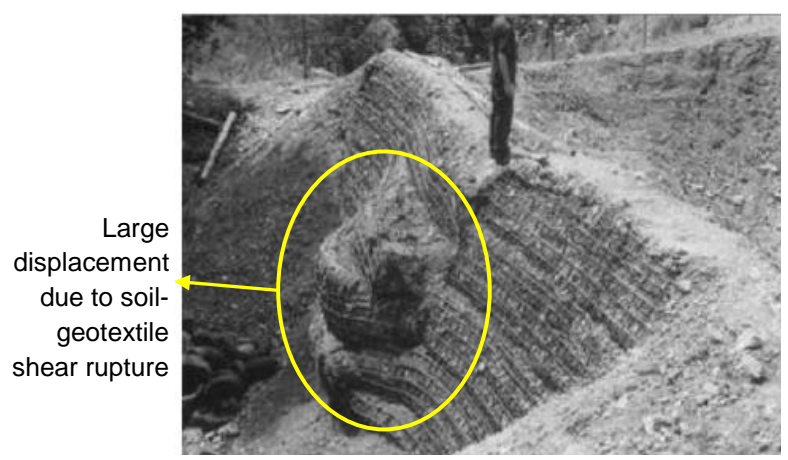

Figure 2. Reinforcement Layers Offer a Preferential Plane for Shear Rupture: Rockfall Protection Embankment [10]

\section{Testing Apparatus and Procedure}

In order to reproduce the shear conditions observed on real structures, a specific apparatus has been developed with the aim of meeting the two main requirements inherent to the application: the pullout velocity and the maximum pull-out displacement. Based on previous studies [12,13], it can be considered that displacements amounting $0.3 \mathrm{~m}$ at the soil-geotextile interface can be observed in the case of rockfall protection structures, and even more in the case of avalanche braking mounds (Figure 2). For rockfall protection structures, these displacements are observed in typically half a second. A pullout velocity in the order of magnitude of $1 \mathrm{~m} / \mathrm{s}$ during pull-out test thus seems to be recommended. This is the most important criterion to meet with the testing apparatus.

It is worth highlighting that these specifications focus on the friction characteristics once shear is initiated. It is indeed believed that the shear triggering conditions, in terms of normal vs. shear stress, are not significantly different to that in static loading conditions. As a consequence, less attention will be paid to the very beginning of dynamic pullout.

The tank used for containing the soil is $0.8 \mathrm{~m}$ in height, $1 \mathrm{~m}$ in length and $0.5 \mathrm{~m}$ in width (Figure 3). It is equipped with a $0.5 \mathrm{~m}$ opening, allowing pulling out the geotextile, $0.2 \mathrm{~m}$ from the tank bottom. Contrary to what is often recommended for static pull-out tests on geotextiles [2,3], no specific arrangement is taken to counter the possible loading of the front wall of the tank. Indeed, there was no guarantee that any of the possible technical solutions would perform satisfactorily during rapid pull-out. Finally, no normal stress loading device is used at this stage of research work. The normal load on the geotextile only results from the weight of the soil above the geotextile.

The clamp used to pull out the geotextile has been specially designed to secure firmly the geotextile without any damage (Figure 4). Indeed, geotextile reinforcement most often includes reinforcing fibers that cannot be cut or bended without altering its mechanical characteristics. The geotextile passes through the slotted metallic cylinder and turns around it. The geotextile is secured as a result of friction on the cylinder as well as in the geotextile overlap zone ( $1 / 4$ of the cylinder perimeter). The clamp is connected to the loading system. 


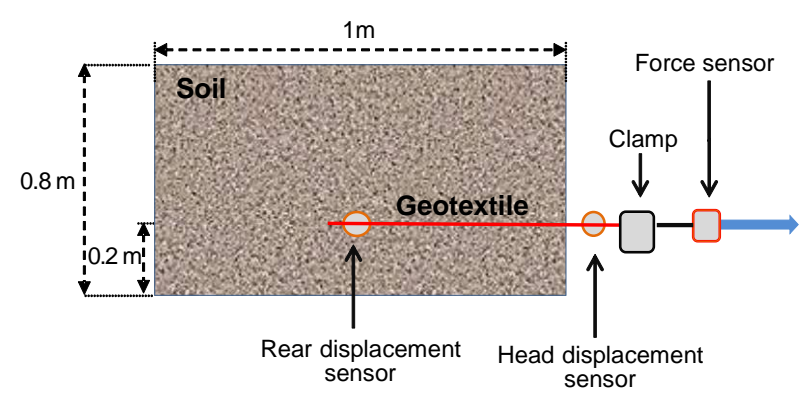

Figure 3. Schematic Vertical Cross-Section of the Tank, Showing the Measurement Points (Side View)

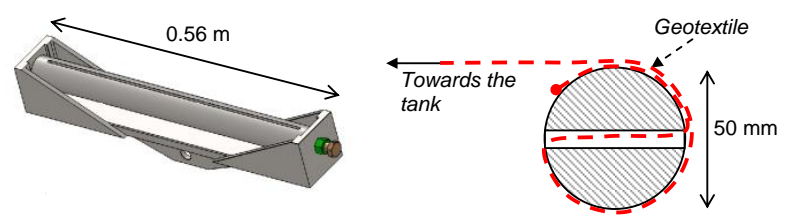

Figure 4. Clamp (Left) and Geotextile Clamping Arrangement Around the Cylinder (Right).

In a pragmatic approach, a simple loading system was developed with the aim of meeting the specifications mentioned above. The dynamic loading is applied to the geotextile by a free falling spherical dead-weight (Figure 5). This 30-kg dead-weight is connected to the clamp via a chain and a cable, passes in three pulleys fixed on a rigid support beam. The chain is initially loose. The test is conducted by dropping the dead-weight from a given height. After a free-fall phase, the dead-weight tightens the chain and cable, applying a dynamic loading on the clamp. The geotextile is then pulled out, progressively braking the dead-weight. Pull-out lasts as long as the dead-weight initial kinetic energy is not totally dissipated by friction on the embedded geotextile surface. As a consequence, increasing the drop height allows increasing pull-out velocity and displacement.

Three real-time measurements are made during the pull-out, using a synchronous acquisition data logger at a $1.7 \mathrm{kHz}$ frequency. The pull-out force is measured using a piezoelectric sensor, $18 \mathrm{kN}$ in measurement range, placed between the clamp and the cable (Force sensor, Figure 3 and Figure 6, right). The positions of the two extremities of the geotextile are measured according to time using potentiometric linear displacement sensors. In the following, front displacement refers to the displacement of the geotextile close to the clamp (Figure 6), while rear displacement refers to the displacement of the goetextile extremity in the tank.

Different data are derived from these measurements. The effective pull-out is calculated from the head displacement measured close to the clamp and taking into account the deformation of the geotextile between the clamp and the tank opening. The head displacement is also used to compute the clamp velocity and acceleration. The friction length is deduced from both the pull-out and from the rear displacement. On one side the length of embedded geotextile decrease with pull-out, but on the other the length of geotextile experiencing friction increase with pull-out [4]. This length can be estimated considering the time when the rear displacement starts increasing and considering a linear increase of the friction length with time. The friction surface is derived from the friction length and considering that friction occurs on both sides of the geotextile strip. The force, which is measured between the clamp and the cable, is used to compute the pull-out force taking into account the inertia forces due to the clamp acceleration. The shear stress is the ratio between the pull-out force and the fiction surface. This calculation is based on the assumption of a uniform distribution of shear along the geotextile strip.

The sample is prepared by progressively filling the tank with soil, with successive $200 \mathrm{~mm}$ thick compacted layers. The unit weight of the soil is determined by placing cups on top of each compacted layer for collecting soil samples. The geotextile is placed on top of the first layer after compaction. Then the rear displacement sensor is attached to the geotextile. Once the tank filling is completed, the geotextile extremity outside the tank is clamped, the front displacement sensor is connected to the geotextile and the clamp is attached to the force sensor.

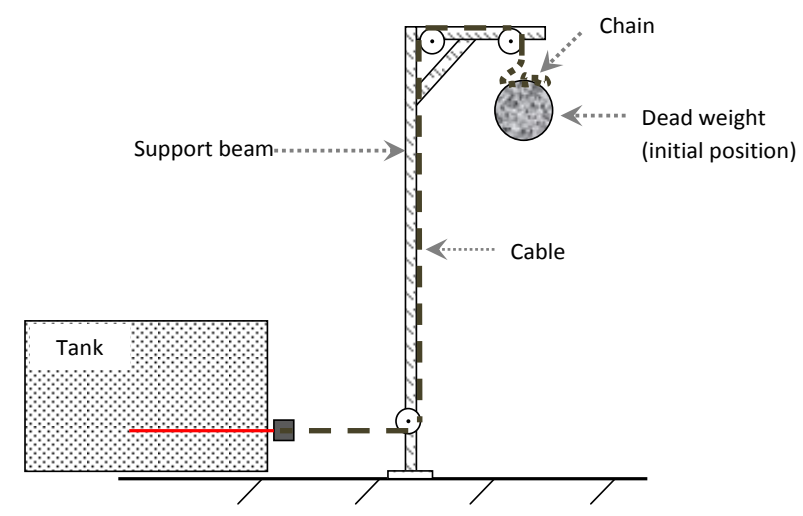

Figure 5. The Rapid Pull-Out is Obtained Dropping a Dead Weight

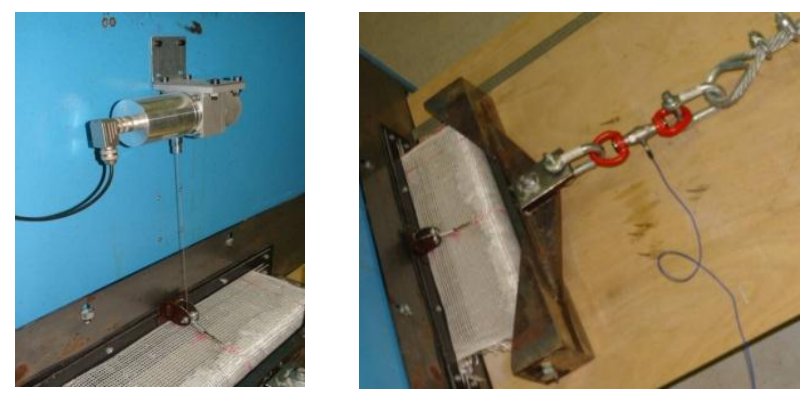

Figure 6. Front Displacement Sensor (Left) and Force Sensor (Right) 


\section{Materials}

Hostun sand (HS) was used as embedding material (Table 2). Hostun sand is originated from a place called Hostun located in the area of Drôme in the South East of France. This fine sand can be considered as representative of soil used to build embankments, as it is a noncohesive granular material. The average unit weight of the sand once compacted was $14.3 \mathrm{kN} / \mathrm{m}^{3}$. The selected geotextile exhibits a high resistance at rupture $(100 \mathrm{kN})$ and a high axial stiffness $(392 \mathrm{kN})$ in order to limit the influence of the geotextile deformation during pullout. This geotextile includes high tenacity polyester yarns. For these tests, the length of geotextile embedded in the tank is $0.49 \mathrm{~m}$, with a width of 0.49 $\mathrm{m}$. The rear displacement sensor is connected to the geotextile, $120 \mathrm{~mm}$ from its dead end. The height of sand above the geotextile is $0.6 \mathrm{~m}$.

\section{Test Conditions}

The response of the geotextile during such a rapid pull-out test is first addressed considering successive tests conducted on a same sample and increasing the dead weight falling height from 0.2 to $1 \mathrm{~m}$ (Table 3 , tests $1 \mathrm{~A}, 1 \mathrm{~B}$ and $1 \mathrm{C}$ ).

This test series was performed successively on one sample with the aim of understanding the mechanisms associated to rapid pull-out of a geotextile. Nevertheless, tests conditions are different from one test to another. The length of the geotextile strip embedded in the sand slightly decreases from one test to the next one. Besides, each test leads to a change in the test conditions in the geotextile vicinity. More precisely, pull-out is thought to result in a variation in the local sand density with consequences on the geotextile pull-out response.

Table 2. Characteristic of the Hostun Sand [15]

\begin{tabular}{lr}
\hline Characteristic & \multicolumn{1}{c}{ Value } \\
\hline Grain size distribution $(\mathrm{mm})$ & $0.16-0.63$ \\
$\mathrm{D}_{10}(\mathrm{~mm})$ & 0.2 \\
$\mathrm{D}_{60}(\mathrm{~mm})$ & 0.42 \\
Angle of friction $\left({ }^{\circ}\right)$ & 38 \\
Unit weight of the grains $\left(\mathrm{kN} / \mathrm{m}^{3}\right)$ & 26.5 \\
Maximum unit weight $\left(\mathrm{kN} / \mathrm{m}^{3}\right)$ & 15.99 \\
Minimal unit weight $\left(\mathrm{kN} / \mathrm{m}^{3}\right)$ & 13.24 \\
\hline
\end{tabular}

Table 3. Test Conditions

\begin{tabular}{ccc}
\hline Test ID & $\begin{array}{c}\text { Drop height } \\
(\mathrm{m})\end{array}$ & $\begin{array}{c}\text { Initial embedded geotextile } \\
\text { length }(\mathrm{m})\end{array}$ \\
\hline 1A & 0.2 & 0.490 \\
1B & 0.5 & 0.489 \\
1C & 1 & 0.485 \\
2 & 1 & 0.490 \\
3 & 1 & 0.490 \\
4 & 1 & 0.490 \\
\hline
\end{tabular}

On the contrary, tests 2 to 4 (Table 3) were conducted on three different samples, in the same conditions, with the same falling height $(1 \mathrm{~m})$. These tests are more relevant in view of the mechanical characterization of the soil-geotextile interaction.

\section{Results}

The measurements made during the first test series and the derived data are presented in Table 4, and Figures 7 to 9 . Similar results and trends have been obtained from conducting two other tests series, in the same conditions. The following trends help in understanding the response of the system to pullout:

- Globally, the maximum values of the pull-out force, pull-out and rear displacements increase during the test succession (Table 4). The force increases to reach a maximum value after around $20 \mathrm{~ms}$ (milisecond), whatever the drop height (Figure 7). In the case of tests 1A and 1B, a 20-ms quasi-plateau is observed, followed by a regular decrease. In the case of test $1 \mathrm{C}$, the force curve exhibits a $10-\mathrm{ms}$ peak, followed by a $20-\mathrm{ms}$ plateau.

- Oscillations are observed on the three force curves, with higher amplitudes for the last test (1C). Small negative pull-out values are observed at the pull-out beginning and the pull-out reaches its maximum after about $50 \mathrm{~ms}$.

- Rear displacement curves are very different from one test to the next one: no displacement during test $1 \mathrm{~A}$, little displacement during test $1 \mathrm{~B}$ with a time lag of about $25 \mathrm{~ms}$ compared to the pull-out displacement and, during test $1 \mathrm{C}$, a displacement of similar amplitude and almost synchronous to the pull-out. At the end of test, a reverse displacement is observed from the three pull-out curves, with maximum amplitude of $2 \mathrm{~mm}$.

- The displacement curves of test $1 \mathrm{C}$ suggest that the geotextile globally moved, allowing estimateing the friction length as well as shear stress, as plotted in Figure 8. This latter figure shows that after $17 \mathrm{~ms}$, all the embedded geotextile move so undergoes friction.

- The friction length decreases after $20 \mathrm{~ms}$ (test $1 \mathrm{C}$, Figure 8), directly resulting from the pull-out of the geotextile strip out of the tank. Shear stress exhibits a very short duration peak at the pullout beginning. The decrease in shear stress is almost linear from 12 to $70 \mathrm{~ms}$.

- The clamp velocity strongly depends on the drop height of the dead weight, with a range of 0.12 to $1.2 \mathrm{~m} / \mathrm{s}$. The clamp velocity curves exhibit differences from one test to another. In particular, a rather linear increase from 20 to $40 \mathrm{~ms}$ is observed for test 1C. 
Table 4. Main Results from the First Test Series

\begin{tabular}{lccc}
\hline & $1 \mathrm{~A}$ & $1 \mathrm{~B}$ & $1 \mathrm{C}$ \\
\hline Max. Pull-out force (kN) & 2.2 & 4.1 & 5.7 \\
Max. Pull-out (mm) & 1 & 6.6 & 27 \\
Max. Rear displ. (mm) & 0 & 1 & 25 \\
Rear disp. Time lag (ms) & - & 33 & 14 \\
Max. clamp velocity (m/s) & 0.12 & 0.31 & 1.23 \\
\hline
\end{tabular}
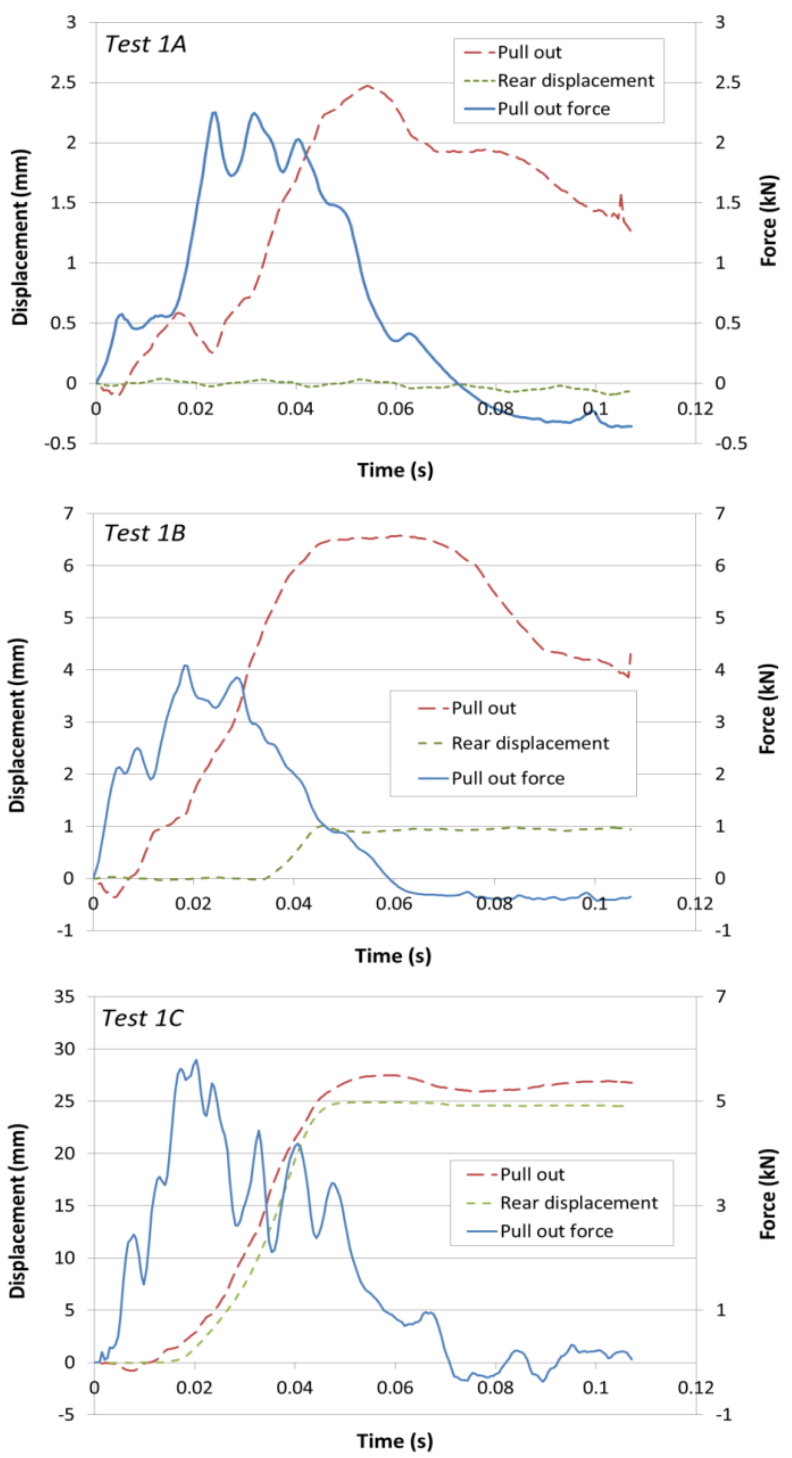

Figure 7. Pull-Out Force, Pull-Out and Rear Displacement measured during the Three Successive Tests

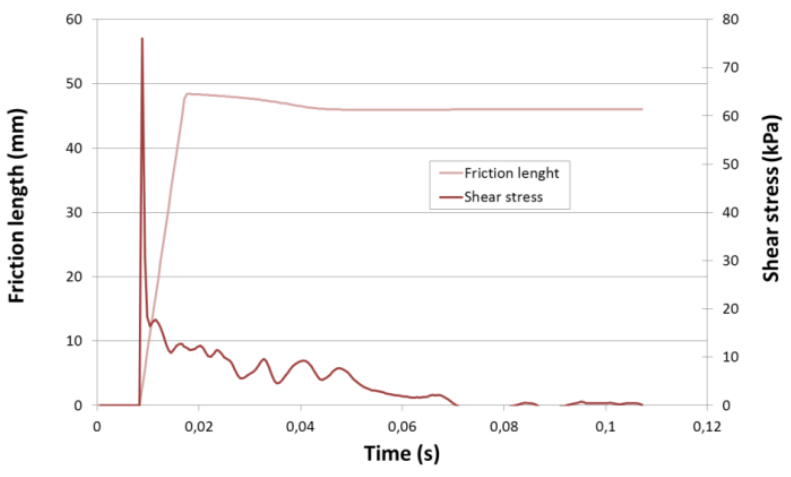

Figure 8. Friction Length and Shear Stress (Test 1C)

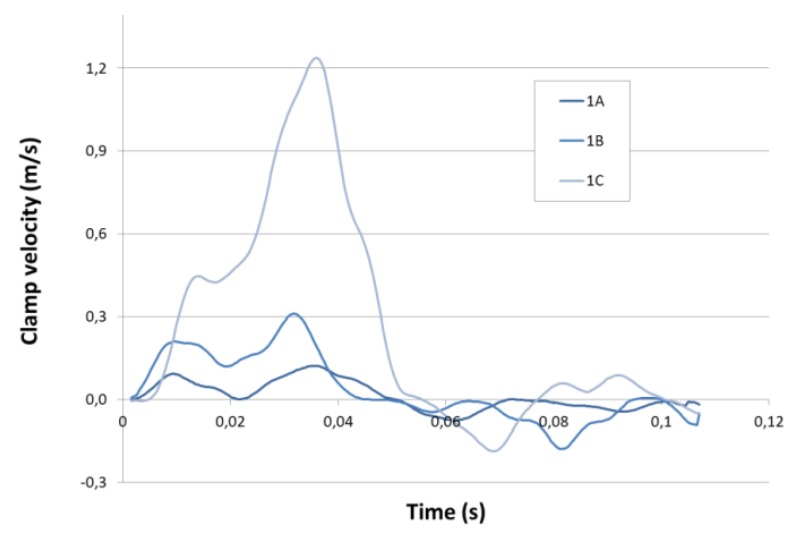

Figure 9. Clamp Velocity with Time during the Three Tests from the First Series
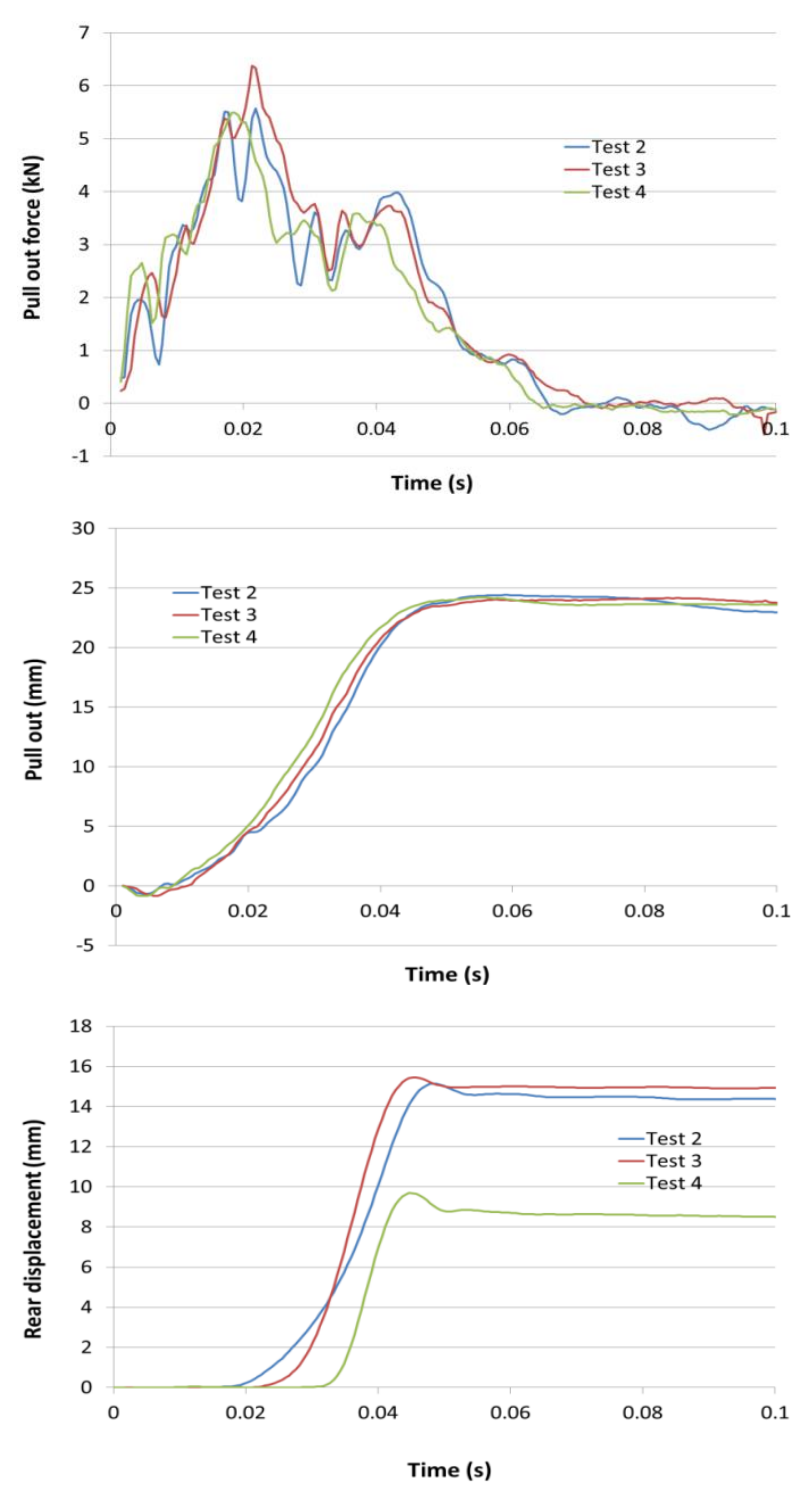

Figure 10. Comparison of the Three Test Results.

The results from tests 2 to 4 are presented in Figure 10 and 11 . The curves of both the pull-out force and the pull-out are similar from test 2 to test 4 . A difference is observed in terms of rear displacement, in particular for test 4 exhibiting a lower displacement. 


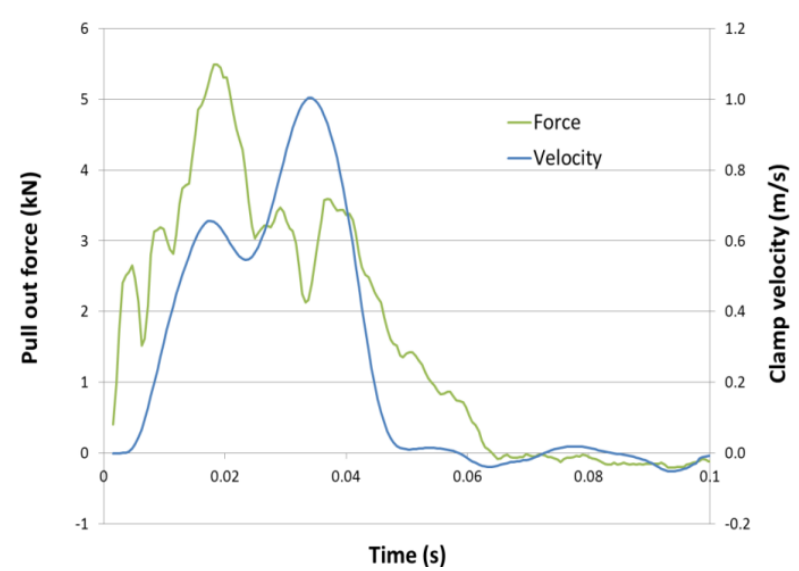

Figure 11. Comparison of Force and Velocity Curves in the Case of Test 3.

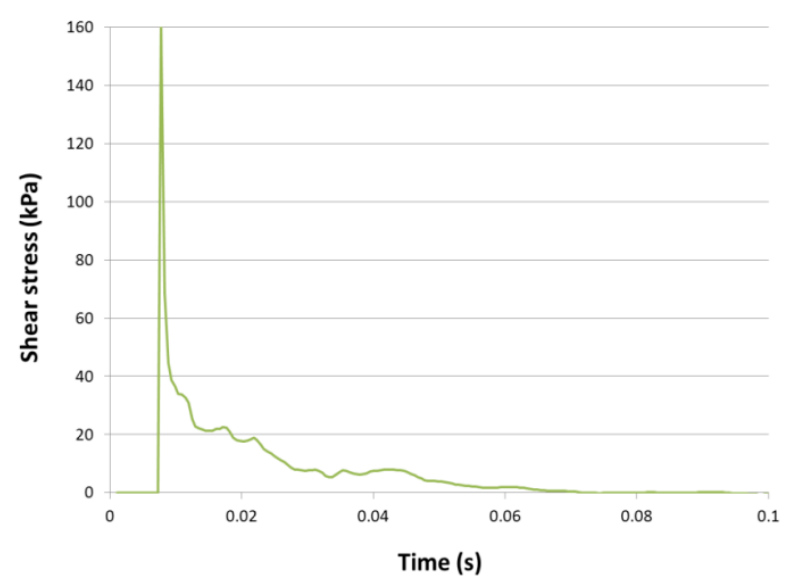

Figure 12. Shear Stress in the Case of Test 3

Pull-out force curves reveal a peak at $20 \mathrm{~ms}$, followed by a quasi-plateau at a lower force value and exhibiting oscillations from 30 to $50 \mathrm{~ms}$. Pull-out reaches its maximum value $(24 \mathrm{~mm})$ at $50 \mathrm{~ms}$ when the pull-out force is less than $2 \mathrm{kN}$. By comparison, the rear displacement is delayed, by a time lag of 10 to $20 \mathrm{~ms}$ and reaches a maximum value 9.6 to 15.5 $\mathrm{mm}$. Figure 11 shows that during the quasi plateau the velocity increases significantly to reach a maximum of $1 \mathrm{~m} / \mathrm{s}$, while the shear stress decreases from 18 to $6 \mathrm{kPa}$ (Figure 12)

The geotextile pull-out resulted from the force transmitted by the loading system to the clamp, and then to the geotextile. During pull-out, energy is dissipated whithin the tank, due to friction at the geotextile-soil interface. As suggested before, pull-out lasts as long as the energy provided by the falling dead weight is not totally dissipated by friction. The higher the falling height, the higher the dead weight velocity, thus the higher its kinetic energy before pulling out. This results in a higher pull-out to dissipate the dead weight kinetic energy. This is confirmed by the pull-out and rear displacements observed from test $1 \mathrm{~A}$ to test $3 \mathrm{~A}$.

\section{Discussion}

When the energy provided to the system is not large enough, only a limited length of geotextile undergoes friction and dissipates energy. It is thought that during tests $1 \mathrm{~A}$ and the beginning of test $1 \mathrm{~B}$, the geotextile is progressively flattened and tightened. Once the geotextile is flat and tightened, any pull-out will result in a whole geotextile sliding, as observed during test $1 \mathrm{C}$. This description is consistent to that proposed for instance by Abdelouhab et al. [1], suggesting that force as well as displacement, are gradually mobilized from the head to the rear of the geotextile strip and that the tail is mobilized after the displacement threshold at the head is reached.

A quasi-plateau is observed on pull-out force curves once all the geotextile moves (tests 1C, 2-4). This quasi plateau follows a peak and lasts typically 30 ms. During this period, all the geotextile slides, undergoing friction and with a significant velocity increase. This is consistent with results presented by Tan et al. [13] after conducting rapid pull-out test with both rough and smooth nails. Their study showed that the post-peak force response was characterized by a sudden rise in pull-out velocity, while the force was virtually unaffected by the variation in pull-out velocity. In practical approach, the fact that all the geotextiles moves allows estimating the shear stress without any assumption concerning the friction length, contrary to the test beginning.

Bias and limitations in the test method can be identified through the presented results. This test method is neither stress-controlled nor strain controlled. Indeed, both the shear rate and the shear stress vary with time. Actually, the loading evolution depends on the response of the tested specimen (i.e. characteristics of the geotextile and soil, normal stress) contrary to static tests for instance. For the same dead weight drop height, the shear rate will depend on the soil-geotextile friction. This, thus, may constitute a limitation of the test method and could be appraised by comparing different geotextile-soil combinations.

Tests $1 \mathrm{~A}$ to $1 \mathrm{C}$ indicate that the rear displacement depends on the flatness of the geotextile before pullout. The difference in rear displacement between test 4 and tests 2 and 3, is also attributed to a difference in the initial geotextile flatness. During these tests, and by contrast with test $1 \mathrm{C}$, the geotextile is tightened and flattened as pull-out increases, during the test. For this reason, and even though the influence on the pull-out force is limited, particular care is recommended when installing the geotextile. The force oscillations observed on tests $1 \mathrm{C}$ are 
believed to result from elasticity of the components of the loading system. In particular, the cable undergoes rapid loading variation and reacts as a spring, which oscillations are very small but large enough to affect the force sensor measurements. Due to these oscillations, the force at the quasi-plateau can only be estimated by averaging.

The method as described above does not allow defining precisely the shear stress at the beginning of pull-out. Indeed, the shear stress peak observed in Figure 8 is thought to be not realistic and may result from the uncertainty associated to the friction surface estimation. On the contrary, pull-out force measured during the quasi-plateau period may be used to determine the shear stress. Nevertheless, questions concerning the shear stress to consider may rise as it significantly decrease with time. Last, this test may not be used to derive a friction angle. This is particularly due to the fact that no specific arrangement has been taken to avoid the wellknown wedge effect developing at the front of the tank.

\section{Conclusion}

An experimental method for measuring the rapid pull-out response of a geotextile has been proposed. The very first tests results are presented and discussed. In the test conditions considered, the shear velocity varied within the specific range 0.1 to $1.2 \mathrm{~m} / \mathrm{s}$. This test method seems promising in addressing the response of soil-geotextile interfaces under dynamic loadings. Nevertheless, improvements concerning the testing apparatus are required. The loading system could be modified to avoid oscillations and specific equipment should be used to increase the normal stress. In the future, complementary sensors are planned to be installed for measuring the displacement of the geotextile in different points and for measuring the dynamic loads on both the bottom boundary and front wall boundary.

\section{Acknowledgement}

The authors are grateful to the research consortium VOR-RNVO for its financial support. The work on this research is partly supported by the Integrated Outstanding Scholarship Program (Beasiswa Unggulan Kemendiknas) from the Ministry of Education of the Republic of Indonesia.

\section{References}

1. Abdelouhab, A., Dias, D., and Freitag, N., Physical and Analytical Modeling of Geosynthetic Strip Pull-Out Behavior, Geotextiles and Geomembranes, 28(1), 2010, pp. 44-53.
2. Aiban, S.A. and Ali, S.M., Interface Frictional Characteristics of Non-woven GeotextileSabkha Sand using Pull-out Tests, Geosynthetics International, 8(3), 2001, pp. 193-200.

3. Palmeira, E.M., Soil-Geosynthetic Interaction: Modelling and Analysis, Geotextiles and Geomembranes, 27(5), 2009, pp. 368-390.

4. Weerasekara, L. and Wijewickreme, D., An Analytical Method to Predict the Pull-out Response of Geotextiles, Geosynthetics International, 17(4), 2010, pp. 193-206.

5. Alobaidi, I.M., Hoare, D.J., and Ghataora, G.S., Load Transfer Mechanism in Pull-out Tests, Geosynthetics International, 4(5), 1997, pp. 509521.

6. Bakeer, R.M., Abdel-Rahmen, A.H., and Napolitano, P.J., Geotextiles Friction Mobilization during Field Pull-out Test, Geotextiles and Geomembranes, 16(2), 1998, pp. 73-85.

7. Fannin, R. J. and Raju, D. M., On the Pull-out Resistance of Geosynthetics, Canadian Geotechnical Journal, 30(2), 1993, pp. 409-417.

8. De, A. and Zimmie, T.F., Estimation of Dynamic Interfacial Properties of Geosynthetics, Geosynthetics International, 5(1-2), 1998, pp. 17-39.

9. Huang, C.-C., Horng, J,-C., Chang, W,-J., Chueh, S,-Y., Chiou, J,-S, and Chen, C,-H., Dynamic Behavior of Reinforced Slopes: Horizontal Acceleration Response, Geosynthetics International, 17(4), 2010, pp. 207-219.

10. Peila, D., Oggeri, C., and Castiglia, C., Ground Reinforced Embankments for Rockfall Protection: Design and Evaluation of Full Scale Tests, Landslides, 4(3), 2007, pp. 255-265.

11. Lambert, S. and Bourrier, F., Design of Rockfall Protection Embankments: A Review, Engineering Geology, 154, 2013, pp. 77-88.

12. Burroughs, D.K., Henson, H.H., and Jiang, S.S., Full Scale Geotextile Rock Barrier Wall Testing, Analysis and Prediction, Proceedings of Geosynthetics '93, Vancouver, Canada, 30 March-1 April 1993, pp. 959-970.

13. Tan, S.A., Ooi, P.H., Park, T.S., and Cheang, W.L., Rapid Pull-out Test of Soil Nail, Journal of Geotechnical and Geoenvironmental Engineering, 134, 2008, pp. 1327-1338.

14. AFNOR, NF EN ISO 13738, Geotextile and Geotextile Related Products: Determination of Pull-Out Resistance in Soil, 2005, pp. 16.

15. Flavigny, E., Desrues, J., and Palayer, B., Le Sable d'Hostun RF, Note Technique, Revue Française de Géotechnique, 53, 1990, pp. 67-69. 